\title{
THE FUNDI EFFECT: ACTIVISM THROUGH EMPOWERMENT
}

\author{
Tony Jamal Lee \\ Afrikan Unity Initiative
}

New ideologies and methodologies are continuously influencing individuals aspiring to create changes to current disparities in society. The Afrikan has been in an everlasting struggle since arriving in the Western Hemisphere. The MAAFA of the Afrikan people ignited the warrior spirit into the very nature of the descendants of Afrika in the Americas. Through this nature, the voice of Afrika rose through many vessels that have influenced people to take action against the oppressive system in which they live. The Civil Rights Movement of the 1950s and 60s in the United States garnered worldwide attention through unremitting efforts to receive equality for all people in the nation by performing acts of civil disobedience.

The participatory democracy strategy of organization used by Ella Baker was greatly productive in grassroots activism, and has the potential to strengthen the political struggles of the present to the height of the movements in times past. Ella Baker was a prominent figure in the black freedom struggle. She was active in fighting for equal rights for Afrikans in America for over five decades. She began in 1930 as a member of Young Negroes Cooperative League. This group focused on the development of economic empowerment in the Black community. As the national director of this organization, Baker structured community cooperatives promoting strong commercial progress. Baker had an early introduction to the injustices that exist with regard to race. She was also raised to resist and battle against those very struggles. She found much pride and strength in the stories of her grandmother surviving many challenging times during enslavement (Sullivan, 1999; Grant, 1998).

Her approach was characterized by an ability to mobilize and influence youth to action. In this work, there will be an analytical examination of how this methodology is equipped to stand the tests of time through what will be called The Fundi Effect. Fundi is a word that is found in both the isi-Zulu and ki-Swahili languages and means person of great knowledge. Not only is the Fundi knowledgeable, but this person also has the distinguished ability to share their information and experiences with the coming generations as to assure that the work is continued.

The Fundi Effect, therefore, describes Baker's approach to activism because she always looked to create leaders rather than simply have fol- 
lowers. The fight against oppression in the United States of America has and will continue to drastically change over time. The Fundi Effect, however, goes beyond the concerns of the present and serves to prepare people to flow with the inevitable changes that occur in life. The Fundi Effect is a method of activism that is capable of being applied intergenerationally, and has the ability to address the reactionary manner with which injustice is dealt in attempts at social movements at present.

The ways in which people in the Black freedom struggle approached the issues they faced determined how instrumental their activity was to the movement. It is here that the examination of participatory democracy will prove its effectiveness. Many sources support this idea of Baker's methodology being transformative and unconventional which appealed to many people who had no organizational affiliation (Grant, 1981; K. Tutashinda, 2010). There are three themes that are consistent throughout the literature and they are as follows: humility, adaptability, and the highly influential nature of The Fundi Effect.

\section{HuMILITY}

"You didn't see me on television; you didn't see news stories about me. The kind of role that I tried to play was to pick up pieces or put together pieces out of which I hoped organization might come. My theory is, strong people don't need strong leaders ${ }^{1 "}$ - Ella Baker

Much of the success of the freedom struggle came from the humble sprit of Ella Baker. She reached out to the masses and developed leaders among those who were already respectable within their communities. The literature suggests that Ella Baker was a person of action with more concern for the progression of the movement than her own public image (Grant, 1998; Ahmad, 2007; Jeffries, 2006; K. Tutashinda, 2010). She was often in contention with Dr. King over this ideology (Ahmad, 2007; Grant, 1981). She was a firm believer that freedom would be won by raising many leaders who worked together cooperatively (Hayden, 2004; Sullivan, 1999; DeLaure, 2008). This was in opposition to the usual type of hierarchal leadership in which everyone depends on one man to lead. Participatory democracy works in opposition to hierarchy (Grant, 1998; Grant, 1981; DeLaure, 2008; K. Tutashinda, 2010). The foundation of this style of activism gives more responsibility to the everyday people struggling for freedom, and it also gives them a more personal connection to the movement. People will surely be more willing to participate if they are regarded to be significant contributors in the struggle. Baker understood this and continually organized from this vantage point. 


\section{INFLUENTIAL}

"The major job was getting people to understand that they had something within their power that they could use, and it could only be used if they understood what was happening and how group action could counter violence ... ." -Ella Baker

Many people and organizations have been either been directly or incidentally influenced by the works and ideas of Ella Baker (Jeffries, 2006; Ahmad, 2007; Grant, 1981). The Fundi Effect allowed Baker to speak to the spirits within people to encourage their potential to materialize into action. Baker also had an invaluable talent to relate to people who were on the fence about activism entirely (K. Tutashinda, 2010; Grant, 1998; DeLaure, 2008). Baker felt that the relationships that she built were imperative to her work. Her organizing tactics made people comfortable with the ideas of fighting for what was right, even if the impact was small. She was special because of her actual interest in the lives of the people she met. This was what truly gave her the significant advantage to develop leaders wherever she went (Grant, 1981; Grant, 1998; K. Tutashinda, 2010; Sullivan, 1999).

Many people have a misconception of this movement as being passive. In fact the efforts of these people were anything but passive. The Black Power Movement was directly birthed from the Civil Rights Movement. This means that there was indeed a radical ideology within the predecessor in order to create such a powerful influence. The audacity of Afrikan students at North Carolina A\&T State University to organize a sit-in at a segregated lunch counter must be categorized as confrontational revolutionary strategy (Ahmad, 2007; Jeffries, 2006; DeLaure, 2008). It was this one event that sparked a total movement of student sit-ins and ultimately created the activist organization known as the Student Non-violence Coordinating Committee (SNCC). SNCC was brought together by Ella Baker who saw that this movement would be successful through the collective energy of the youth (Ahmad, 2007; Jeffries, 2006; Igus, Ellis, Patrick, \& Wesley, 1991; Grant, Ella Baker: Freedom Bound, 1998). The Fundi Effect was at work as she was able to identify the leadership potential in those students. She was one of the only people with the insight and capability to take the student sit-in initiative that had at the time become national, and organize these young minds into a collective unit. She was the mother of SNCC (Ahmad, 2007; Hayden, 2004; Sullivan, 1999). Baker intentionally advised the young students to create their own organization, as opposed to being a 
sub-group under the SCLC umbrella (Grant, 1998; Ahmad, 2007; Grant, 1981).

\section{AdAPTABILITY}

"In order for us as poor and oppressed people to become part of a society that is meaningful, the system under which we now exist has to be radically changed. . . It means facing a system that does not lend its self to your needs and devising means by which you change that system." - Ella Baker

Baker saw this as an opportunity to utilize the group centered leadership strategy as the foundation of this new organization with young minds that would be more willing to accept her wisdom. Her ability to mentor and mobilize individuals while not needing to be publicized for her work, gave her the irreplaceable value of reaching people through all generations. Her message resonated through both the Civil Rights and Black Power movements (Ahmad, 2007). There is a clear advantage to the group centered activism of Ella Baker. Baker began to distance herself from strict organizational relations as their methods proved to be static (DeLaure, 2008; K. Tutashinda, 2010; Grant, 1998; Grant, 1981). The hierarchy within these organizations generally opposed participatory democracy as the primary approach from which to battle the race struggle in the nation. Baker related to the new radical forms of activism exhibited in the youth and was able to see the benefits of their approach when other older people thought them to be too reckless (Grant, 1981; Hayden, 2004; K. Tutashinda, 2010; DeLaure, 2008). She was also able to temper their resentment toward those who were not of radical thought, and instead showed how to work alongside them. Many of these young minds initiated the Black Power movement which is referred to by some as the evolution of the Civil Rights era (Jeffries, 2006; Ahmad, 2007; DeLaure, 2008).

The Fundi Effect adapted to the dynamic forces that any movement encounters and successfully continued through the changes in thought and method at the time. The adaptability of The Fundi Effect extends to the ways in which people in the freedom struggle could successfully resist the attacks that were brought on by the government. With the knowledge of how the Counter Intelligence Program (COINTELPRO) of the FBI worked to disrupt and destroy all freedom struggles in this nation, it may have been better if there were no identifiable leaders in any of the organizations struggling for equal rights (Jeffries, 2006; Ahmad, 2007). Leader-centered groups are at risk because when the shepherd is re- 
moved the sheep scatter. However, when each person in the organization is a leader they become more difficult to infiltrate (Jeffries, 2006; Ahmad, 2007; DeLaure, 2008). With a conscious mind of how all of these events happened in the past, The Fundi Effect, if used in a concerted effort, could help the struggle for freedom progress without destructive consequences.

\section{Central Argument}

In the aftermath of the zenith of the Black freedom struggle, there has been an era of lethargic activism when there is any at all. The twenty-first century version of so-called activism is lacking the basis through which all movements are fueled: love. The Fundi Effect extends beyond the anger and disgust that motivates the recent efforts of attaining justice. The fire of anger quickly dissipates as time passes. The Fundi Effect initiates movements from the enraging moments. Though there must be a genuine love for the issues and the people for this to properly function. Love is what permeates through the inevitable impediments that come along with fighting for justice. The Fundi Effect can only be operated with the correct motives. It is too of ten that people in the Black community are only seen fighting for justice when the press is present, but as the news coverage dies their involvement does as well.

The participatory democratic tactics of Baker are encompassed within The Fundi Effect, but are not the totality of it. The very essence of Baker's approach to the people with whom she engaged adds potency to this technique. In order to eradicate the apathy of the people, empathy must be reestablished within the Afrikan community. People have to understand that they are the leaders who they are awaiting. The Fundi Effect makes every community member responsible for the desired change. Baker argued that strong people are not in need of strong leaders, and this model carries accountability (Grant, 1998). This model also is quite difficult to infiltrate with divisive schemes as J. Edgar Hoover did to obliterate the Black Power movement. This is why Baker began to weaken her associations with particular organizations. Organizations are easy to identify, but the organized efforts of individuals through grassroots movement creates great challenges to those who oppose the struggle. People will then be prepared when cases such as the murders of Trayvon Martin, Tamir Rice, Michael Brown, Freddie Gray, or the events surrounding the Jena 6 trials occur.

The Fundi Effect has the capacity to turn the youth's rebellious attitudes into something constructive promoting progress. Baker had a heart for the youth, and she realized that their energy could be used to establish new ways to approach social action. This means that through educating the young people of the organization in their history it is possible to 
awaken many dynamic ways in which to face socio-political obstacles. The Fundi Effect embraced the sit-ins that were called radical and made them into a respected movement. It can do the same for the youth of today and beyond by the elders embracing the rebellion of the youth and directing this energy towards beneficial aims.

Along with the formerly mentioned aspects, The Fundi Effect also contains the tools of organization and strategy. The emotions that follow major injustices such as the recent Michael Brown and Tamir Rice executions tend to overshadow the logical ways to handle these situations. An accurate study of the social movements of the past indicates that there was strategic method behind the activities that ensued (Marable, 2000; Ahmad, 2007). The case of Plessey vs. Ferguson was a premeditated endeavor by the NAACP to bring the subject of segregation to the Supreme Court. The Montgomery bus boycott was also planned similarly with Rosa Parks intentionally getting arrested that day as a catalyst to the events that followed (Franklin \& Moss, Jr., 1947; Igus, Ellis, Patrick, \& Wesley, 1991).

Strategy is at the heart of any functional tactic. Baker was able to strategically facilitate the young people of SNCC to organize their efforts to desegregate lunch counters. The Fundi Effect strategizes in similar ways as the aforementioned cases with one exception, the people are encouraged to help the facilitator best cater their needs. There have been marches and demonstrations in reaction to the injustices from the Rodney King to the Eric Garner case, but there was no clear direction to these actions. The new activists have taken a look at the surface of the movements of the past with an un-analytical lens of the ground work taken to make these acts successful. A cohesive and unified mission must be at the center of any productive struggle. Baker organized people by showing them how the issues are relative to their lives. Once this was done it was not difficult to establish unity among the people and create strategies to address the problems that existed. The Fundi Effect must be carried out by those who are respected in their communities and used to organize and prepare people to fight injustice anytime and anywhere. Information is transferred from one generation to the next and that is the basis of this methodology. This methodology is not only strongly based from the model of Baker's participatory democracy, but is the evolution of what she generated. There is a consciousness that must be developed in order for this function.

The vessel through which the Fundi Effect is employed is through Afrikan Unity Initiative, Inc. Afrikan Unity Initiative is an organization catered toward creating a better world for Afrikans and all people through interactive service and education. It is called an initiative because the word exemplifies proactiveness, which is a necessity when 
fighting injustice. All of the initiatives are designed to work in any place around the globe in order for the methods to help people of Afrikan descent wherever they may be in the Diaspora. With respect to the fact that Baker had cut ties with formal organizations Afrikan Unity Initiative, Inc. operates more as a global network of people working towards building and sustaining strong ties across the Afrikan Diaspora.

\section{CONCLUSION}

The Fundi Effect is a method of activism that is capable of being applied inter-generationally, and has the ability to address the reactionary manner with which injustice is dealt in attempts at social movement in the present. In the current system of individualism and reactionary activism, The Fundi Effect has the ability to penetrate a listless generation. Social injustices are bound to become more apparent and overt if these unorganized and languid efforts persist. The best way for these methods to be applied would be for an information transfer from the Ivory Tower to the street. Baker is no longer around to teach these methods, and the access to her work is presently not as available to everyone as it should be. The black freedom struggle continues and has many obstacles that have many layers to address. One major form of oppression that plagued many Afrikan people was colonization from European powers. As with enslavement, colonization has been defeated. The problem is that the psychological conditioning which was utilized in both systems sustains the oppression into the present.

The Fundi Effect works proactively to engage people in community development and global cooperation. No longer will the people of Afrikan descent be exploited due to isolation. Through the Afrikan Diaspora Dialogues the issues facing people globally will be known throughout the network and will be addressed as the problem of all Afrikan people. When diamonds are being unjustly taken from Sierra Leone, Afro-Peruvians, Nigerians, and Afrikans in the United States will stand in opposition to that act. The isolation of the Afrikan Diaspora has allowed for racism and the oppression of Afrikan peoples to continue for many generations. The divide between scholars and lay people must be broken. A focus on youth leadership development is also an intricate piece of this being realized. The Fundi Effect permeates into the spirit of humanity, and is developed to pass knowledge forward in order to ensure that social injustice is battled in every generation with the same or even more vigor than their predecessors. Baker felt that the relationships that she built were imperative to her work. Her organizing tactics made people comfortable with the ideas of fighting for what was right, even if the impact was small. She was special because of her actual interest in the lives of the people she met. This was what truly gave her the significant 
advantage to develop leaders wherever she went. This is the essence of The Fundi Effect. The sharing of this philosophy should be implemented in a way that would make all who adhere to this design a Fundi in their own right.

\section{Works Cited}

Ahmad, M. (2007). We Will Return in the Whirlwind: Black Radical Organization 1960-1975. Chicago: Charles H. Kerr Publishing Company.

Collier-Thomas, B. (1998). Daughters of Thunder: Black Women Preachers and their Sermons 1850-1979. San Francisco: JosseyBass Publishers.

DeLaure, M. B. (2008). Planting Seeds of Change: Ella Baker's Radical Rhetoric. Women's Studies in Communications, 1-29.

Fanon, F. (1961). Wretched of the Earth. New York: Grove Press.

Franklin, J. H., \& Moss, Jr., A. A. (1947). From Slavery to Freedom. New York: McGraw-Hill Inc.

Freire, P. (1970). Pedagogy of the Oppressed. London: Penguin Books.

Gates Jr., H. L., \& Marable, M. (2000). A Debate on Activism in Black Studies. In M. Marable, Dispatches from the Ebony Tower: Intellectuals Confront the African American Experience (pp. 187-191). New York: Columbia University Press.

Gates Jr., H. L., \& Marable, M. (2000). A Debate on Activism in BlaMarableck Studies. In M. Marable, Dispatches from the Ebony Tower: Intellectuals Confront the African American Experience (pp. 187-191). New York: Columbia University Press.

Grant, J. (Director). (1981). FUNDI: The Story of Ella Baker [Motion Picture].

Grant, J. (1998). Ella Baker: Freedom Bound. New York: John Wiley \& Sons Inc.

Hayden, C. (2004). Ella Baker As I Knew Her: She Trusted Youth. Social Policy, 101-104.

Hilliard, A. G. (1997). SBA: The Reawkening of the African Mind. Gainsville, FL: Makara Publishig Company.

Igus, T., Ellis, V. F., Patrick, D., \& Wesley, V. W. (1991). Book of Black Heroes Vol. II: Great Women in the Struggle. New Jersey: Just Us Books Inc.

Jeffries, J. L. (2006). Black Power in the Belly of the Beast. Chicago: University of Illinois Press. 
K. Tutashinda, D. (2010). The Grassroots Political Philosophy of Ella Baker: Oakland, California Applicability. The Journal of Pan-African Studies, 25-43.

Marable, M. (2000). Dispatches from the Ebony Tower: Intellectuals

Confront the African American Experience. New York: Columbia University Press.

Sullivan, L. Y. (1999). Ella Baker. Social Policy, 54-58. 